\title{
AN APPRAISAL OF THE IMPACT OF THE ELECTRICITY POWER SECTOR REFORM PROJECT ON INDUSTRIALIZATION IN NIGERIA
}

\author{
Thaddeus C. Eze \\ Chukwuemeka Odumegwu Ojukwu University, Igbariam.
}

\begin{abstract}
:
This paper examines the effect of the electricity power sector reform Act on industrialization in Nigeria. Power has been a recurring problem in Nigeria in what has been commonly referred to as the electricity gap. The federal government of Nigeria came up with a comprehensive legislation to boost power supply. The implementation of this legislation has led to a partial privatization of the hitherto fully state-owned parastatal that was responsible for electricity generation and supply. The paper examines the outcome of the Electricity Power Sector Reform Act (EPSRA), 2005 on the rate and level of industrialization in Nigeria. It was found that the Act has not, in any way, significantly improved electricity supply in Nigeria. Consequently, Nigerian industries are still groaning under increased cost of production occasioned largely by epileptic power supply. The absence of prepaid digital meters for the billing of many electricity consumers has also worsened the plight of industries that use electricity, and which are forced to pay for electricity supplied under an estimated billing system. The study adopted the doctrinal research approach.
\end{abstract}

Introduction: The Relationship between Electricity Power Supply and Industrialization: The economies of the world are heavily reliant on energy and Nigeria is not an exception. Energy is the greatest force driving every economy and the activities within them (Alam, 2006). There is, thus, an undeniable nexus between electricity supply and industrialization. Studies have revealed that the problem of inadequate power supply increases the cost of production of Nigerian industries by about $40 \%$ (AdeniKinju 2005).

Where there is inadequate supply of power, Small and Medium Scale Industries (SME'S) are the hardest hit. This, in turn, has a spiralling effect on other sectors of the economy and employment generation is adversely affected. It is, therefore, important to examine the key provisions of the EPSR Act, 2005 and its implementation to establish whether there has been a boost in electricity power supply. This is because an increase in electricity power supply will certainly lead to an increase in industrialization and industrial output. According to Emovon et al (2010), a sustainable power supply system is an effective and indispensable condition or boost for the rapid industrial and economic growth of any nation.

The high cost of electricity generation from private sources has been shown to be one of the major challenges facing SME'S in Nigeria. Aremu and Adeyemi (2011) and Adenikinju and Alaba (2010) found in their studies that there was a positive relationship between energy supply and industrial output but stated that other factors such as the adoption of advanced and energy efficient technology was also necessary to combine with adequate electricity supply in contributing to increased industrial output. In other words, energy reforms should be carried out side by side with technological reforms for there to be a boost in industrial output.

While agreeing with this position, it is important to note that technology reforms or the adoption of advanced technology will be a mirage in a context of epileptic power supply.

Thus, there appears to be a unidirectional relationship between industrialization and power supply wherein industrialization is the dependent variable while power supply is the 
independent variable. It is thus clear that energy has become a very important factor of production outside land, labour and capital (Alams, 2006).

\section{Background to the Electricity Power Sector Reform Project in Nigeria:}

The history of electricity in Nigeria dates back to 1896 when the first power plant was built in Lagos (Umbu, 2017). The Nigerian Electricity Supply Company (NESCO) was established in 1929 as the first public electricity utility company in Nigeria. The Public Works Department (PWD) was then empowered to build electricity plants in Nigeria. In 1950, the Electricity Corporation of Nigeria (ECN) Ordinance was enacted (Statute 15 (1950). Electricity generation, transmission and distribution remained in the hands of ECN until 1972 when the National Electricity Power Authority (NEPA) was born. The Commercialization Privatization Act of 1988 came on board as part of the effort to address the electricity gap.

The problem was not solved by the partial commercialization and privatization process. A nineman committee was set up by the Obasanjo administration with the aim of restructuring the sector to become private sector-driven, with the government standing in as a regulator. It was this committee that eventually drafted the EPSR Act of 2005.

\section{Steps taken under the ESPR Act of 2005:}

The most important step taken under the Act is the unbundling of NEPA into six generation companies, popularly called GENCO'S-one transmission company wholly owned and operated by the Federal Government, and eleven distribution companies popularly called DISCO'S. In the unbundling process, the Federal Government sold $80 \%$ of the equity shares in the GINCO'S to private people while retaining $20 \%$. It also sold $60 \%$ of the equity shares to the DISCO'S while retaining $40 \%$. It understandably retained $100 \%$ equity shares in the transmission company possibly to enable it maintain an effective regulation of the industry.

The act contained provisions that could enable the federal government reverse the process by cancelling the licenses of the participating private companies who breached any of the provisions of the Act.

\section{THE OUTCOME OF THE UNBUNDLING PROCESS:}

The government, in licensing the distribution companies, ended up creating geographical distribution cartels. This defeated the stated aim of the Act to wit, creating a competitive electricity market in Nigeria. The DISCO'S are doing everything possible to deprive the users of electricity proper billing methods by insisting on estimated bills as against providing prepaid metres for both domestic and industrial users, even when the users are prepared to pay for such metres.

The implication for industrialization is that the privatization process has not led to any significant increase in the volume of affordable electricity supplied to the industrial sector. Rather, industries are still running on diesel and their costs of production are on the increase. Many industries are forced to close down and new ones are very reluctant to commence business.

\section{The Way Forward:}

The federal government should review the entire privatization process with a view to finding answers to some pertinent questions. First, what exactly is the role of the distribution companies? Why are the distribution companies reluctant to metre electricity consumers 
including industries even when they are ready to pay for the meters? Are the skilled players yet in the generation and distribution process? What is the sense in creating geographical monopolies for the distribution companies instead of allowing more than one distribution company in a particular geographical area so as to avail the consumers of the freedom of choosing who to purchase electricity from?

Finally, what is the input of the distribution companies in the replacement and modernization of obsolete and out-dated transmission equipment?

\section{Conclusion:}

It is important to deal with the problem of electricity supply for there to be any meaningful progress in the industrialization effort in Nigeria. There are flaws in the privatization efforts of the federal government in the Nigerian electricity sector which must be corrected before the production of the quantum of electricity needed to drive industrialization can be achieved.

The potentials for the generation of adequate electricity for industrialization are there in Nigeria but the distribution angle must be effectively managed so as to catalyze the process of better generation and transmission.

\section{References}

Adenikinju, A.F. (2005). Analysis of the Cost of Infrastructure Failure in a Developing Economy: the case of the electricity sector in Nigeria. African Economic Consortium Research, vol.148.

Akinbola, O.A. (2017) The Power Sector and its Impact on Industrialization of Business in Nigeria, Archives of Business Research, vol.5(12)

Alams, M.S. (2006). Economic Growth with Energy. Retrieved on the $20^{\text {th }}$ November 2008.

Commercialization and Privatization Act, 1988, S.I

Emovon, I., et al. (2011) Power Generation in Nigeria: Problems and Solutions. International Conference of Nigerian Association of Energy Economists. NAEE, Abuja

Electricity Corporation of Nigeria Ordinance, 1950

Electricity Power Sector Reform Act, 2005, Part II

Morimato, R. and Hope, C. (2009) "The Importance of Electricity Supply on Economic Growth in Sri Lanks", Judge Institute of Management Research Paper

Okafor, E.O (2008) "Development: Crisis of the Power Supply and implications for the Industrial Sector in Nigeria," Kanla Raj Journal, Vol.6 pp 83-92.

Rabiu, A. (2009) "The cost of electricity in Nigeria" in International Association of Energy Economists, First Quarter,15-17

Umbu, E. (2017) "Electricity Law: A brief history of Nigerian electricity" Available at https://legalresearchesnigeria Accessed May 2017. 